\title{
Artikel
}

\section{Tailormade regelgeving voor windturbineparken op de Noordzee}

\author{
Mr. E.M.N. Noordover en mr. A. Drahmann*
}

\section{Inleiding $^{1}$}

Op 16 oktober 2014 is het voorstel voor de Wet windenergie op zee (hierna: het wetsvoorstel of de wet) aan de Tweede Kamer aangeboden. ${ }^{2}$ Zoals de naam van het wetsvoorstel al doet vermoeden, betreft het de regelgeving voor de realisatie en exploitatie van windturbineparken op zee. Het wetsvoorstel bevat onder meer een nieuw wettelijk instrument, namelijk het kavelbesluit. In dit artikel wordt het voorgestelde wettelijk systeem uiteengezet. Daarbij zal waar nodig een aantal vragen worden gesteld, in de hoop dat deze gedurende het wetgevingsproces nog beantwoord kunnen worden. Hierna zullen eerst de hoofdlijnen van het wetsvoorstel worden geschetst (par. 2). Vervolgens zullen de belangrijke rechtsfiguren worden toegelicht: het kavelbesluit (par. 3), het waterplan (par. 4) en de windvergunning (par. 5).

\section{Hoofdlijnen van het wetsvoorstel}

Het kabinet wil meer energie duurzaam opwekken en dit realiseren door onder meer windparken op zee te bouwen. Artikel 1 van het wetsvoorstel definieert een

Mr. E.M.N. (Erwin) Noordover is advocaat bij Stibbe. Mr. A. (Annemarie) Drahmann is advocaat bij Stibbe en promovenda aan de afdeling staats- en bestuursrecht van de Universiteit Leiden.

1. Dit artikel is afgerond op 10 november 2014.

2. Kamerstukken II 2014/15, 34058, 2. 'windpark' als 'een samenstel van voorzieningen waarmee elektriciteit met behulp van wind wordt geproduceerd, waarbij onder een samenstel van voorzieningen wordt verstaan alle aanwezige middelen die onderling met elkaar zijn verbonden voor de productie van elektriciteit met behulp van wind'. Met een 'samenstel' wordt bedoeld dat het moet gaan om een groep windmolens, aldus de memorie van toelichting. ${ }^{3}$

De wens van het kabinet om meer duurzame energie op te wekken volgt uit de Richtlijn hernieuwbare energie, op grond waarvan Nederland moet zorgen voor een aandeel energie uit hernieuwbare bronnen van minstens 14 procent in $2020 .{ }^{4}$ In het in september 2013 gesloten Energieakkoord voor Duurzame Groei ${ }^{5}$ is als doelstelling opgenomen een operationeel windvermogen op zee van $4450 \mathrm{MW}$ in 2023. Voor de realisatie van voornoemde doelen vormt deze wet een wezenlijke stap. Hierna komen achtereenvolgens de essentie van het wetsvoorstel (par. 2.1) en welke problemen het wetsvoorstel beoogt op te lossen (par. 2.2) langs. Daarna wordt ingegaan op de gevolgen van het wetsvoorstel voor al verleende (water)vergunningen voor de bouw van een windpark (par. 2.3).

\subsection{Essentie van het wetsvoorstel}

De kern van het wetsvoorstel is kort te beschrijven. In een structuurvisie (par. 4) worden de gebieden aangewezen waar windparken op zee zullen worden gerealiseerd. Per gebied zullen vervolgens kavelbesluiten (par. 3) worden genomen waarin staat onder welke voorwaarden vergunningen voor de bouw en exploitatie van een windpark kunnen worden verleend. Ten behoeve van

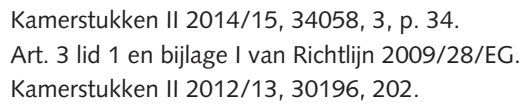


dit kavelbesluit worden al de benodigde onderzoeken, zoals een milieueffectrapport (MER) en een passende beoordeling in het kader van de Natuurbeschermingswet 1998 (Nbw 1998), verricht. De derde stap is de hiervoor genoemde verlening van vergunningen op grond van het wetsvoorstel (hierna: windvergunning) (par. 4). Zolang voor de bouw van windparken op zee nog subsidie verstrekt moet worden, kunnen initiatiefnemers een aanvraag voor een subsidie indienen. De beschikbare subsidiegelden zullen worden verdeeld door middel van een subsidietender. Als een subsidie wordt verstrekt aan een initiatiefnemer, dan wordt vervolgens ook de windvergunning aan deze initiatiefnemer verleend. Indien in de toekomst geen subsidie meer nodig is, dan zal er, in plaats van een subsidietender, een vergunningentender worden georganiseerd. De initiatiefnemer aan wie een windvergunning wordt verleend, zal worden verplicht om het windpark binnen een bepaalde termijn in gebruik te nemen. Uitgangspunt van de wetgever is dat een windpark binnen vier jaar na het verkrijgen van een subsidiebeschikking operationeel moet zijn en dient te zijn gebouwd volgens de stand der techniek van dat moment. ${ }^{6}$

\subsection{Problemen van het huidige wettelijke stelsel}

Met het wetsvoorstel wordt beoogd het realiseren van windparken op zee te vereenvoudigen en versnellen. In de memorie van toelichting bij het wetsvoorstel wordt een viertal problemen van het huidige wettelijke stelsel beschreven. ${ }^{7}$ Een belangrijk probleem betrof de noodzaak om een watervergunning te verkrijgen alvorens subsidie kon worden verkregen. Illustratief in dit verband is dat er tussen 2005 en 200879 initiatieven voor het realiseren van een windpark zijn geweest, waarvoor negentien watervergunningen zijn aangevraagd, twaalf vergunningen zijn verleend en slechts voor drie subsidie is verleend. Dat betekent dat vele initiatiefnemers hoge kosten hebben moeten maken voor onderzoeken ten behoeve van de benodigde vergunningen, zonder dat dit heeft gerealiseerd in de daadwerkelijke bouw van een windpark. De afwezigheid van een koppeling tussen subsidie en vergunningverlening wordt dan ook als problematisch ervaren.

Een tweede probleem betrof een gebrek aan sturingsmogelijkheden in locaties en in tijd voor het Rijk. Om de afgesproken doelstellingen te halen zullen naar verwachting de komende jaren tien nieuwe windparken moeten worden gerealiseerd. Hiervoor is het van belang dat de voor windparken geschikte gebieden optimaal benut worden. Dit is volgens de wetgever in het huidige systeem niet mogelijk, omdat watervergunningen worden verleend op basis van het principe 'wie het eerst komt, wie het eerst maalt'. Dit heeft tot gevolg dat als een aanvrager een windpark midden in een geschikt gebied als eerste aanvraagt, de kans groot is dat de rest van dat geschikte gebied niet goed of helemaal niet meer bruikbaar is voor andere windparken. Het wetsvoorstel

6. Kamerstukken II 2014/15, 34058, 3, p. 4.

7. Kamerstukken II $2014 / 15,34058,3$, p. 5-6 beoogt een optimale indeling van de geschikte gebieden te bewerkstelligen door middel van het kavelbesluit. Bij deze indeling kan ook rekening worden gehouden met de aansluiting van de windparken op het hoogspanningsnet op land (waarop in par. 4.3 wordt ingegaan).

Een derde probleem is de lange doorlooptijd tussen het aanvragen van de vergunningen en de daadwerkelijke realisatie van een windpark. Hiervoor is al toegelicht dat voordat subsidie werd verleend eerst een vergunning nodig was en dat met dit proces veel tijd was gemoeid. Daarnaast is van belang dat een vergunning tot nu toe werd verleend op basis van een concreet turbinetype en concrete indeling van het windpark. ${ }^{8}$ Tegen de tijd dat daadwerkelijk met de bouw van het windpark gestart kon worden, kon de initiatiefnemer de voorkeur hebben voor een ander turbinetype en andere indeling van het windpark dan oorspronkelijk aangevraagd, waardoor de verleende vergunningen weer gewijzigd moesten worden. Het wetsvoorstel wil dit oplossen door het mogelijk te maken dat de initiatiefnemer pas na de vergunningverlening een inrichtingsplan indient. Hierop wordt in paragraaf 5.3 ingegaan. Een laatste aspect dat met de doorlooptijd te maken heeft, is dat diverse vergunningen nodig zijn, die elk hun eigen procedure volgen. Het wetsvoorstel probeert deze procedures zo veel mogelijk te coördineren.

Een vierde en laatste probleem dat in de memorie van toelichting wordt beschreven, is de verbinding van de windparken op zee met het landelijk hoogspanningsnet op het land. Dit kan door middel van een net op zee dan wel een radiale aansluiting. Voordat het kavelbesluit wordt genomen, zal deze keuze gemaakt worden, zodat initiatiefnemers hier rekening mee kunnen houden bij het uitwerken van hun plannen. Hierop wordt in paragraaf 4.3 ingegaan.

\subsection{Aandacht voor al verleende watervergunningen}

Zoals hiervoor al is gesteld, zijn er tot nu toe twaalf watervergunningen voor windparken verleend. Twee parken zijn al gebouwd en drie parken zullen nog worden gebouwd. Van de overige vergunningen is de verwachting dat deze niet gebruikt gaan worden, temeer omdat voor deze vergunningen geen subsidie meer zal worden verleend. ${ }^{9}$ Om deze reden is overgangsrecht opgenomen voor de al verleende vergunningen. Artikel 34 lid 1 van het wetsvoorstel bepaalt dat het verbod om zonder windvergunning niet van toepassing is op windparken waarvoor al een watervergunning ${ }^{10}$ én een subsidie zijn verleend. Dit lid ziet dus op de al bestaan-

8. Hoewel de Afdeling bestuursrechtspraak van de Raad van State recent het gebruik van marges in een vergunning voor een windpark op land heeft aanvaard, ABRvS 25 juni 2014, ECLI:NL:RVS:2014:2354.

9. De mogelijkheid om subsidie voor windenergie op zee aan te vragen is vooralsnog komen te vervallen met ingang van 1 oktober 2014 met een wijziging van de Regeling aanwijzing categorieën duurzame energieproductie 2014 (Stcrt. 2014, 27266)

10. Of haar voorganger: een vergunning op grond van de Wet beheer rijkswaterstaatswerken 
de windparken en de drie windparken waar een concreet uitzicht op realisatie is. Dit heeft tot gevolg dat de windparken waarvoor wel al een watervergunning maar nog geen subsidie is verleend, niet meer gerealiseerd kunnen worden. Daarom bepaalt het tweede lid dat deze 'oude' watervergunningen van rechtswege vervallen op het moment dat de wet in werking treedt. Opvallend is dat in de memorie van toelichting wordt gesproken over het 'bij wet intrekken' van de vergunningen, terwijl artikel 34 lid 2 spreekt over het 'vervallen' van de vergunning. ${ }^{11}$

In de memorie van toelichting wordt ingegaan op de vraag of de houders van de vergunningen die van rechtswege zullen vervallen, aanspraak kunnen maken op een schadevergoeding (nadeelcompensatie). Volgens de wetgever is dit niet het geval, onder meer omdat het intrekken van de watervergunningen voorzienbaar zou zijn geweest. ${ }^{12}$

Ten slotte is na de inwerkingtreding van de wet geen watervergunning meer vereist. De windvergunning is afdoende. Dit volgt uit artikel 31, dat een nieuw artikel 6.5a aan de Waterwet toevoegt. Terzijde merken wij op dat voor het bouwen van een windpark in de exclusieve economische zone (EEZ) ook geen omgevingsvergunning op grond van de Wet algemene bepalingen omgevingsrecht (Wabo) vereist is. Ten eerste omdat de Wabo niet van toepassing is in de EEZ en ten tweede omdat in artikel 32 van het wetsvoorstel een nieuw artikellid aan artikel 8.3 Wabo wordt toegevoegd dat (kort samengevat) bepaalt dat de Wabo niet van toepassing is op windparken die (gedeeltelijk) in de territoriale zee liggen en waarop deze wet van toepassing is. ${ }^{13}$

\section{Het kavelbesluit}

Uitgangspunt van het wetsvoorstel is dat windparken slechts gerealiseerd kunnen worden op locaties (kavels) die zijn aangewezen in een kavelbesluit. Artikel 1 definieert een kavelbesluit als een 'besluit waarin een kavel en een tracé voor een aansluitverbinding zijn aangewezen'.

Kavels worden op grond van artikel 3 lid 2 van het wetsvoorstel uitsluitend aangewezen binnen een gebied dat is aangewezen in het, in de volgende paragraaf beschreven, nationaal waterplan. In het kavelbesluit wordt bepaald waar en onder welke voorwaarden een windpark gebouwd en geëxploiteerd mag worden. Van belang is dat het kavelbesluit geen recht tot het oprichten en exploitatie van het windpark toekent. Dit gebeurt pas bij de verlening van de windvergunning. Hierna zal eerst kort worden ingegaan op de inhoud (par. 3.1) en wijze van totstandkoming (par. 3.2) van het kavelbesluit. Vervolgens worden twee belangrijke aspecten van de vast- stelling van het kavelbesluit belicht, namelijk het MER (par. 3.3) en de natuurbescherming (par. 3.4).

\subsection{Inhoud van het kavelbesluit}

Zoals hiervoor opgemerkt, wijst het nationaal waterplan de gebieden aan waarbinnen kavelbesluiten kunnen worden genomen (hierna: windgebieden). Deze windgebieden zijn in de meeste gevallen ruimer dan de economisch efficiënte omvang van een windpark. Op dit moment is de efficiënte omvang van een windpark ongeveer $350 \mathrm{MW}$. Daarom zal een windgebied waarin bijvoorbeeld plaats is voor $1400 \mathrm{MW}$ worden opgedeeld in meerdere kavels. Bij de keus voor de omvang en precieze locatie van een kavel zullen onder andere de eigenschappen van het gebied (zoals de ligging van kabels en leidingen of andere windparken), de schaalbaarheid van een eventueel net op zee en de beschikbare subsidie in het jaar waarvoor het kavelbesluit wordt voorbereid, een rol spelen. ${ }^{14}$

In het kavelbesluit moet een balans worden gevonden tussen beoogde onzekerheidsreductie voor de initiatiefnemers en behoud van voldoende flexibiliteit voor de realisatie van het windpark. De onzekerheidsreductie beoogt initiatiefnemers de zekerheid te geven dat de locatie geschikt is voor de realisatie van een windpark en de voorwaarden die hiervoor bestaan. Dit geeft initiatiefnemers de nodige kaders voordat zij gaan concurreren bij het verkrijgen van subsidies. De kaders mogen echter niet zo stringent zijn dat initiatiefnemers geen flexibiliteit meer hebben bij de realisatie van het windpark. ${ }^{15}$ Het is uitdrukkelijk niet de bedoeling dat in het kavelbesluit het aantal windmolens en de exacte locatie van elke mast worden bepaald. Zo wordt het mogelijk om meerdere verschillende varianten van het windpark te realiseren, mits de minimale jaarlijkse elektriciteitsproductie wordt behaald.

Artikel 4 lid 1 bepaalt dat de minister van Economische Zaken (hierna: de minister of minister van EZ) aan een kavelbesluit een aantal regels en voorschriften moet verbinden. De regels uit het kaderbesluit kunnen ook anderen dan de vergunninghouder binden. ${ }^{16}$ De aan een kavelbesluit te verbinden regels en voorschriften moeten in ieder geval betrekking hebben op:

1. de rechten en andere belangen van derden (zoals regels over medegebruik, bijvoorbeeld duurzame niet-bodemberoerende visserij, mariene aquacultuur en recreatie);

2. de bescherming van het milieu (zoals het opnemen van een minimale en maximale hoogte van de wiek, een minimale afstand tussen de turbines en de wijze van fundatie);

3. de bescherming van Natura 2000-gebieden, waaronder de verplichting om compenserende maatregelen te treffen; 
4. de voorwaarden die voortvloeien uit de Flora- en faunawet (Ffw);

5. doelmatig ruimtegebruik (zoals in elk geval de buitenste contouren van het windpark of een maat voor de minimale elektriciteitsproductie per jaar (rotoroppervlak));

6. de termijn waarvoor de vergunning wordt verleend; en

7. financiële voorwaarden. ${ }^{17}$

In het kavelbesluit wordt dus de geldigheidsduur van de windvergunning voorgeschreven. $\mathrm{Na}$ het verstrijken van deze termijn moet het windpark worden verwijderd. Om te waarborgen dat dit ook gebeurt, kan op grond van artikel 28 lid 3 bij het kavelbesluit het stellen van financiële zekerheid voor de opruimkosten worden voorgeschreven. Daarnaast kan worden geëist dat nog andere zekerheden worden gesteld 'ten genoegen van' de minister. Ten behoeve van de financiering zal de zekerheid in termijnen moeten worden gesteld. ${ }^{18}$

Verder moet op grond van artikel 4 lid 2 een kavelbesluit uit een aantal verplichte onderdelen bestaan. Dit zijn:

1. een beschrijving van de te treffen voorzieningen, gericht op het ongedaan maken, beperken of compenseren van de gevolgen van de bouw en exploitatie van een windpark;

2. een beschrijving van de tijdelijke matregelen en de tijdelijk te treffen voorzieningen die nodig zijn voor de verwezenlijking van het windpark;

3. de aanduiding op één of meer topografische of geografische kaarten van de geografische omvang van het kavel en de ligging van het tracé van de aansluitverbinding;

4. de uitkomsten van het onderzoek naar meteorologische omstandigheden, bodemgesteldheid, stromingen en golfhoogtes, milieukundig bodemonderzoek, archeologisch onderzoek en overig milieukundig onderzoek; en

5. de termijn waarbinnen de minister de gevolgen van de ingebruikneming van een kavel onderzoekt en een opgave van de daarbij te onderzoeken milieuaspecten.

Onderdeel 5 ziet op de periodieke monitoring tijdens de operationele fase van het windpark. Met name de effecten op de fauna zullen onderdeel zijn van deze monitoring. In de memorie van toelichting wordt gesteld dat door deze monitoring de voorwaarden die aan de Ffwvrijstelling in het kavelbesluit worden gesteld, kunnen worden versoepeld of verzwaard. ${ }^{19}$

Bij het nemen van het kavelbesluit moet de minister een belangenafweging maken. Artikel 3 lid 3 somt de vijf relevante belangen op, namelijk:

1. de vervulling van maatschappelijke functies van de zee, waaronder het belang van een doelmatig ruimte-

17. Kamerstukken II 2014/15, 34058, 3, p. 18.

18. Kamerstukken II 2014/15, 34058, 3, p. 46-47

19. Kamerstukken II 2014/15, 34058, 3, p. 37. gebruik van de zee (hierop wordt in par. 4 nader ingegaan omdat de maatschappelijke functietoekenning aan de Noordzee is uitgewerkt in onder andere het nationaal waterplan, maar in essentie kan gedacht worden aan scheepvaartfunctie, duurzame energieopwekking in zee en het archeologisch erfgoed onder water);

2. de gevolgen van een aanwijzing voor derden (waaronder in ieder geval de belangen van de visserij en kabels en leidingen vallen);

3. het milieubelang, waaronder het ecologisch belang;

4. de kosten om een windpark in het gebied te realiseren (deze kosten kunnen aanleiding zijn voor een bepaalde gefaseerde uitrol, waarop in par. 4.3 wordt ingegaan);

5. het belang van een doelmatige aansluiting van een windpark op een net. ${ }^{20}$

De afstemming tussen windparken en andere activiteiten van nationaal belang heeft reeds gedeeltelijk plaatsgevonden in het nationaal waterplan (zie par. 4). De afweging van andere belangen moet nog plaatsvinden bij de voorbereiding van een kavelbesluit. Dit is bijvoorbeeld het geval bij de mijnbouw. ${ }^{21}$

Ten slotte is van belang dat artikel 4 lid 4 bepaalt dat het verboden is te handelen in strijd met het kavelbesluit en de daaraan verbonden regels en voorschriften. Dit heeft tot gevolg dat de in het kavelbesluit opgenomen voorschriften niet meer aan de vergunning hoeven te worden verbonden. Bij schending van deze voorschriften kan de minister handhavend optreden op basis van het kavelbesluit. Daarnaast is van belang dat het kavelbesluit het kader zal vormen voor de aanvragen voor een windvergunning. Initiatiefnemers zullen dus op het moment dat zij een aanvraag indienen (als het goed is) al een duidelijk beeld hebben van de verplichtingen waaraan zij moeten gaan voldoen.

\subsection{Wijze van totstandkoming en rechtsbescherming}

Het kavelbesluit wordt op grond van artikel 3 door de minister, in overeenstemming met de minister van infrastructuur en milieu (IenM), genomen. Op het vaststellen van een kavelbesluit is de uniforme openbare voorbereidingsprocedure van de Algemene wet bestuursrecht $(\mathrm{Awb})$ van toepassing. In afwijking van deze Awb-procedure kan eenieder (en niet alleen belanghebbenden) een zienswijze indienen tegen het ontwerpbesluit. Het wetsvoorstel bevat geen regeling om een kavelbesluit aan te kunnen vragen. Hiermee beoogt de wetgever de sturingsmogelijkheden bij de minister te laten liggen. ${ }^{22}$ Artikel 11 bevat mogelijkheden om het kavelbesluit te wijzigen of in te trekken.

20. Kamerstukken II 2014/15, 34058, 3, p. 10, 13 en 35-36

21. Kamerstukken II 2014/15, 34058, 3, p. 11-12

22. In de MvT wordt er echter wel op gewezen dat art. 6:2 Awb voorziet in de mogelijkheid om bezwaar te maken tegen het niet nemen van besluiten (Kamerstukken II 2014/15, 34058, 3, p. 19). 
Tegen een kavelbesluit is beroep in één instantie mogelijk. De bevoegde rechter is, op grond van artikel 30 aanhef en onder 2 de Afdeling bestuursrechtspraak van de Raad van State (hierna: de Afdeling).

Artikel 8 verklaart hoofdstuk 1, afdeling 2, van de Crisis- en herstelwet van overeenkomstige toepassing. Dit heeft onder meer tot gevolg dat de Afdeling binnen zes maanden na afloop van de beroepstermijn uitspraak moet doen. ${ }^{23}$ Ook kunnen decentrale overheden geen beroep instellen tegen het kavelbesluit en moeten beroepschriften direct de beroepsgronden bevatten.

Ten slotte bevat artikel 9 de bevoegdheid voor de minister om een voorbereidingsbesluit te nemen. Hiermee kan een locatie waarvoor een kavelbesluit wordt voorbereid, worden beschermd tegen veranderingen in en in de nabijheid van die locatie die de verwezenlijking van een windpark in gevaar zouden kunnen brengen. Tegen een voorbereidingsbesluit staan op grond van artikel 30 aanhef en onder 1 geen bezwaar en beroep open.

\subsection{Het kavelbesluit en de m.e.r.}

De memorie van toelichting merkt het kavelbesluit aan als een besluit als bedoeld in artikel 7.1 van de Wet milieubeheer $(\mathrm{Wm})$, waarvoor volgens de $\mathrm{Wm}$ een MER moet worden opgesteld. ${ }^{24}$ De oprichting, wijziging of uitbreiding van een windturbinepark is nu al in het Besluit milieueffectrapportage (Besluit m.e.r.) aangewezen als een activiteit waarvan moet worden beoordeeld of er belangrijke nadelige gevolgen voor het milieu optreden, de zogeheten m.e.r.-beoordeling. Wij gaan er, gelet op de te verwachten milieueffecten van een windpark en de wens om na het kavelbesluit geen nader milieuonderzoek meer te laten verrichten, van uit dat het kavelbesluit niet m.e.r.-beoordelingsplichtig zal zijn, maar direct project-MER-plichtig wordt. Hiervoor zal het kavelbesluit al in onderdeel $\mathrm{C}$ van de bijlage bij het Besluit m.e.r. moeten worden aangewezen en is een wijziging van het Besluit m.e.r. nodig.

\subsubsection{Procedure MER}

Uit de memorie van toelichting volgt dat de zogeheten uitgebreide procedure van toepassing is. ${ }^{25}$ Deze procedure verloopt - kort samengevat - als volgt. De minister is, als bevoegd gezag bij het nemen van het kavelbesluit, ook op grond van artikel 7.22 lid $2 \mathrm{Wm}$ bevoegd ten aanzien van het opstellen van het MER. De procedure zal beginnen met de kennisgeving van het voornemen een kavelbesluit vast te stellen en mogelijk met het nemen van een voorbereidingsbesluit op grond van artikel 9 van het wetsvoorstel. Op dat moment is voor alle partijen in de windsector, maar ook voor andere belanghebbenden op de Noordzee, duidelijk op welk gebied en welke locatie binnen het zoekgebied een kavelbesluit genomen gaat worden. Vervolgens kan in een concept-

23. In de MvT wordt ons inziens abusievelijk gesproken over een termijn van zes maanden na ontvangst van het verweer (Kamerstukken II 2014/15, 34058, 3, p. 19)

24. Kamerstukken II 2014/15, 34058, 3, p. 23.

25. Kamerstukken II 2014/15, 34058, 3, p. 11. notitie reikwijdte en detailniveau worden toegelicht welke aspecten op welke wijze in het MER onderzocht gaan worden. Op deze conceptnotitie kunnen door eenieder zienswijzen worden ingediend. Tijdens de daaropvolgende periode van het schrijven van het MER kan afstemming plaatsvinden met de windsector en andere belanghebbenden op de Noordzee. Deze afstemming zal uiteindelijk haar beslag krijgen in een (ontwerp)kavelbesluit. Het (definitieve) MER zal samen met het ontwerpkavelbesluit ter inzage worden gelegd en eenieder heeft dan de mogelijkheid een zienswijze in te dienen.

\subsubsection{Inhoud MER}

Aan de inhoud van het MER worden diverse eisen gesteld. De belangrijkste is dat het voorgenomen project zelf wordt beschreven, zijnde het windpark en het tracé voor de aansluiting op het land. Verder moeten de redelijkerwijs in beschouwing te nemen alternatieven en de motivering voor de keuze van deze alternatieven, de bestaande toestand van het milieu en de referentiesituatie worden opgenomen. Uit de memorie van toelichting blijkt dat in ieder geval de uiterste varianten in de turbinetypes en fundatietechnieken zullen moeten worden beschreven in het MER. ${ }^{26}$

Het doel van de wetgever is dat als een project-MER is opgesteld voor een kavelbesluit, geen project-MER nodig is voor de windvergunning. ${ }^{27}$ Het MER voor het kavelbesluit zal hiervoor wel een bepaalde bandbreedte moeten hebben. Uitsluitend binnen deze bandbreedte kan de initiatiefnemer een windvergunning aanvragen zonder MER-plicht. Het is dan ook voor initiatiefnemers van belang dat zij direct aan het begin van de m.e.r.-procedure voor het kavelbesluit kijken of de reikwijdte van het MER voldoende is om het gewenste windpark te realiseren.

De vraag is vervolgens wat er zal gebeuren als later blijkt dat het project-MER niet (meer) voldoet voor de windvergunning. Wij verwachten dat in dat geval het bevoegd gezag het kavelbesluit opnieuw zal vaststellen met een geactualiseerd project-MER. Dit is immers ook wat de minister zal doen met een gedateerde of onvolledige passende beoordeling, waarop in het volgende onderdeel wordt ingegaan. Om dit te voorkomen is het wenselijk om de verlening van een windvergunning in de tijd zo dicht mogelijk aan te laten sluiten op de vaststelling van een kavelbesluit. Het opnieuw moeten vaststellen van een kavelbesluit vanwege een gedateerd project-MER zal immers onwenselijke vertraging in de realisatie van de windparken op zee opleveren. In de praktijk zou eerst nog kunnen worden gekeken naar de mogelijkheid om toch ten behoeve van de windvergunning nader onderzoek te doen, om het tijdsverlies met het vaststellen van een kavelbesluit te voorkomen.

Het voorgaande doet ook de vraag rijzen in hoeverre het doel van de wetgever om de windvergunning (naast het

26. Kamerstukken II 2014/15, 34058, 3, p. 23.

27. Kamerstukken II 2014/15, 34058, 3, p. 23. 
kavelbesluit) niet aan te wijzen als een m.e.r.-(beoordelings)plichtig besluit haalbaar is. Uit artikel 2 in samenhang met artikel 4 lid 2 en bijlage II van de m.e.r.richtlijn volgt dat de wetgever moet borgen dat voor windturbineparken een vergunning vereist is waarbij een m.e.r.-beoordeling wordt uitgevoerd. Uit de beoogde systematiek van de wet leiden wij af dat de wetgever het kavelbesluit aanmerkt als de vergunning als bedoeld in de m.e.r.-richtlijn. Het kavelbesluit is echter nog niet de vergunning waarmee het recht tot oprichten van een windpark wordt verleend. Dit recht wordt immers pas bij de windvergunning toegekend. Een windvergunning is daarmee vergelijkbaar aan een omgevingsvergunning voor het oprichten van een windpark op land, welk besluit wél project-MER-plichtig is. De wetgever lijkt de windvergunning echter meer aan te merken als een soort bouwvergunning, waarbij geen beoordeling van de milieueffecten meer hoeft plaats te vinden. Een dergelijke constructie is niet onmogelijk, mits is verzekerd dat alle milieueffecten ten tijde van het kavelbesluit zijn beoordeeld. Er kan dan worden gesteld dat voldaan is aan de eisen van de m.e.r.-richtlijn. Voorgaande toont het belang van een goede en weloverwogen uitvoering van het milieuonderzoek ten behoeve van het kavelbesluit, zodat geen discussie meer kan ontstaan over de mate waarin een windvergunning nog andere dan wel zwaardere milieueffecten heeft.

Ten slotte is het opvallend dat in de memorie van toelichting in het geheel niet wordt ingegaan op de vraag of voor het kavelbesluit, naast een project-MER, ook een plan-MER moet worden opgesteld. Deze plicht kan bestaan via twee wegen, namelijk (1) als het kavelbesluit kaderstellend is of (2) vanwege het opstellen van een passende beoordeling.

Het waterplan (waarop in par. 4 wordt ingegaan) is in ieder geval wel plan-MER-plichtig. Het is echter gebruikelijk dat plan-MER-plichtige plannen stapelen, bijvoorbeeld bij een gemeentelijke structuurvisie en een plan-MER-plichtig bestemmingsplan. De enkele aanwezigheid van een plan-MER voor het waterplan sluit dan ook niet zonder meer een plan-MER-plicht voor het kavelbesluit uit. Een plan is kaderstellend als het een kader vormt voor de toekenning van toekomstige vergunningen voor projecten die m.e.r.-(beoordelings)plichtig zijn. De Wm acht een plan in elk geval kaderstellend als in dat plan een locatie wordt aangewezen of locaties worden overwogen voor een projectMER-plichtige activiteit. De wetgever beoogt de windvergunning niet project-MER-plichtig te laten zijn, waarmee het kavelbesluit niet kaderstellend lijkt te zijn. Hiervoor is echter al de vraag naar voren gekomen of dit haalbaar gaat zijn. Als een windvergunning toch projectMER-plichtig blijkt te zijn, dan zal een kavelbesluit ook plan-MER-plichtig worden. Verder wijzen kavelbesluiten de locaties voor windparken (nader) aan, waarbij naar kan worden verwacht een afweging van de (begrenzing van de) locaties plaatsvindt. Dit geeft ook een indicatie van het plankarakter van het kavelbesluit.
Daarnaast bepaalt artikel 7.2a Wm dat een plan waarvoor een passende beoordeling moet worden gemaakt ook plan-MER-plichtig is. Voor het kavelbesluit moet (hoogstwaarschijnlijk) ook een passende beoordeling worden opgesteld (zie par. 3.4). Ook hierdoor rijst de vraag of het kavelbesluit toch als een plan moet worden aangemerkt, ondanks de wens van de wetgever om het kavelbesluit enkel als een besluit aan te merken. Het valt op dat de wetgever hier geen overweging aan wijdt, terwijl dit toch aanzienlijke gevolgen heeft.

Overigens maakt de komst van de Omgevingswet een nadere toelichting op de m.e.r.-regelgeving bij het kavelbesluit des te belangrijker. Onder de huidige regelgeving bevat het Besluit m.e.r. nog een lijst van aangewezen plan-MER-plichtige plannen, waarbij het kavelbesluit (vooralsnog) niet zal worden genoemd. De wetgever heeft echter het voornemen geuit om onder de Omgevingswet enkel nog te werken met de eisen van kaderstelling en het opstellen van een passende beoordeling. Onder de Omgevingswet bestaat dan ook meer ruimte om de discussie over het plankarakter van het kavelbesluit te voeren.

Gezien het belang dat de wetgever hecht aan de beperking van het milieuonderzoek tot de vaststelling van het kavelbesluit en het daarmee uitsluiten van dergelijk onderzoek bij de windvergunning verdient het aanbeveling dat de wetgever de houdbaarheid van deze systematiek in het licht van de m.e.r.-regelgeving nader onderbouwd. Weliswaar lijkt de beoogde wetssystematiek niet onaanvaardbaar, maar om discussie in de te verwachten procedures tegen de besluitvorming te voorkomen is een nadere onderbouwing volgens ons wel noodzakelijk.

3.4 Het kavelbesluit en de natuurbescherming Bijzondere aandacht verdient de regeling voor de natuurbescherming, zoals deze is neergelegd in de artikelen 5, 6 en 7. Om de besluitvorming te versnellen wil de wetgever dat al ten behoeve van het kavelbesluit de benodigde natuuronderzoeken worden verricht en niet pas bij de windvergunningverlening. Daarnaast wordt in het wetsvoorstel onder meer, vooruitlopend op de inwerkingtreding van de Wet natuurbescherming, ${ }^{28}$ een uitzondering gemaakt op de verbodsbepalingen uit de Ffw. Hierna zal eerst worden ingegaan op de samenloop met de NB-wet 1998 en daarna op de Ffw. ${ }^{29}$

\subsubsection{Het kavelbesluit en de Nbm 1998}

De Nbw 1998 betreft de bescherming van habitats door het aanwijzen van Natura 2000-gebieden. Het kader van deze gebiedsbescherming volgt mede uit de Habitatrichtlijn en de Vogelrichtlijn. ${ }^{30}$ Doel van de wetgever is dat de beoordeling van de natuuraspecten van een windpark deel uitmaakt van het kavelbesluit en dat geen afzonderlijke Nbw 1998-vergunning meer vereist is.

28. Kamerstukken II 2011/12, 33348, 2.

29. Volledigheidshalve wordt opgemerkt dat sinds 1 januari 2014 de NBwet 1998 en de Ffw ook van toepassing zijn op activiteiten in de EEZ.

30. Zie voor een uitgebreide beschrijving van dit Europese kader de MvT, p. 13-15. 
Artikel 5 bepaalt om deze reden dat artikel 19d Nbw 1998 (vergunningplicht) en artikel 19kc Nbw 1998 (meldingsplicht) niet van toepassing zijn op projecten of andere handelingen waarop het kavelbesluit betrekking heeft.

De Nbw 1998 maakt onderscheid tussen 'projecten' en 'andere handelingen'. De bouw en exploitatie van een windpark is volgens de wetgever aan te merken als een 'project' in de zin van de Nbw 1998. Een voorbeeld van een andere handeling kan het onderhoud van het windpark zijn. Verder moeten de bouwvoorbereidende werkzaamheden, de bouw zelf en de exploitatie van een windpark waarschijnlijk als één project worden gezien. ${ }^{31}$

De tweede volzin van artikel 5 bepaalt dat op het vaststellen van het kavelbesluit wel artikel 19j Nbw 1998 (dat betrekking heeft op plannen) van overeenkomstige toepassing is. ${ }^{32}$ Dit heeft tot gevolg dat voor het kavelbesluit (hoogstwaarschijnlijk) een passende beoordeling zal moeten worden opgesteld. In deze passende beoordeling zullen de uiterste varianten die het kavelbesluit mogelijk maakt, moeten worden onderzocht op de gevolgen voor de natuur. Uit de memorie van toelichting blijkt uitdrukkelijk dat het mogelijk is dat de gevolgen voor de natuur niet weggemitigeerd kunnen worden en dat een zogenaamde ADC-toets zal moeten worden verricht. Als gevolg daarvan moet vóór vaststelling van het kavelbesluit worden onderzocht of er geen alternatieven (A) zijn. De bevordering van windenergie kan, volgens de wetgever, worden aangemerkt als een dwingende reden van openbaar belang (D). Daarnaast moeten in het kavelbesluit compenserende maatregelen $(\mathrm{C})$ worden voorgeschreven. ${ }^{33}$

Het zal voor initiatiefnemers heugelijk in de oren klinken dat de passende beoordeling, gelijk aan het MER, al ten tijde van het kavelbesluit door de minister zal worden opgesteld. De vraag is echter wat de waarde van deze systematiek in de praktijk zal blijken. Ten eerste zal de uiteindelijk gekozen variant van het windpark binnen de in de passende beoordeling betrokken uitersten moeten liggen. Ten tweede is op het tijdstip waarop het kavelbesluit wordt vastgesteld nog onbekend welke materialen en technieken voor het windpark zullen worden gebruikt. Dit betekent dat het mogelijk is dat, om de gevolgen voor de natuur vast te kunnen stellen, bij de verlening van de windvergunning de op dat moment bekende technieken en materialen alsnog onderzocht moeten worden. Ten slotte moet de inhoud van de passende beoordeling op het moment dat de vergunning wordt aangevraagd nog actueel zijn. ${ }^{34}$ Ook de Raad van State heeft in zijn advies gewezen op dit risico van de

31. Kamerstukken II 2014/15, 34058, 3, p. 38.

32. Overigens zou men zich de vraag kunnen stellen waarom art. 19j NBwet 1998 slechts van 'overeenkomstige' toepassing is. In de MvT wordt niet ingegaan op de vraag in hoeverre het kavelbesluit kwalificeert als een plan als bedoeld in dat artikel.

33. Zie voor een aantal voorbeelden Kamerstukken II 2014/15, 34058, 3, p. 16.

34. Kamerstukken II 2014/15, 34058, 3, p. 16-17 verouderde passende beoordeling. ${ }^{35}$ Wellicht is het voor de initiatiefnemer een geruststelling dat in de memorie van toelichting wordt gesteld dat als de passende beoordeling niet meer actueel is op het moment van vergunningverlening, het kavelbesluit opnieuw moet worden vastgesteld op basis van een geactualiseerde passende beoordeling en niet alsnog een passende beoordeling voor de windvergunning door de initiatiefnemer moet worden opgesteld. ${ }^{36}$ Een wijziging van het kavelbesluit zal echter wel tijd kosten. Het verdient dan ook, vanuit het oogpunt van de natuuraspecten, aanbeveling om zo min mogelijk tijd te laten verstrijken tussen het vaststellen van het kavelbesluit en de verlening van de windvergunning.

\subsubsection{Het kavelbesluit en de Ffm}

De Ffw betreft de bescherming van dier- en plantensoorten. Ook het kader van deze soortenbescherming wordt mede gevormd door de Habitatrichtlijn en de Vogelrichtlijn. Deze bescherming geldt ook buiten Natura 2000-gebieden en beschermt zelfs individuele exemplaren van beschermde soorten. Voor het realiseren van windparken is met name de bescherming van vogels, vleermuizen, de in de Noordzee voorkomende zeezoogdieren en bepaalde vissoorten relevant. Uit eerdere onderzoeken is gebleken dat gevolgen van windparken vooral kunnen bestaan uit geluidsoverlast voor zeezoogdieren en vissen tijdens de bouw (door bijvoorbeeld heiwerkzaamheden) en aanvaringskansen voor kustbroedvogels en trekvogels na het operationeel worden van het park. ${ }^{37}$

De Ffw beschermt meer soorten dan strikt noodzakelijk is op grond van de Habitatrichtlijn en verbiedt ook meer handelingen dan vereist wordt door de Europese richtlijnen. Vooruitlopend op de inwerkingtreding van de Wet natuurbescherming beoogt de wetgever de discrepantie tussen de nationale wetgeving en Europese richtlijnen (de zogenaamde 'nationale koppen') weg te nemen in artikel 6 door de verbodsbepalingen van artikel 9 en $10 \mathrm{Ffw}$ gedeeltelijk niet van toepassing te verklaren op windparken in zee. In essentie houden de wijzigingen in dat (1) als een dier niet opzettelijk door een windpark gedood wordt de Ffw niet wordt overtreden, en (2) niet meer elke verstoring van vogels verboden is, maar slechts verstoringen die van wezenlijke invloed zijn. ${ }^{38}$

De grens tussen opzettelijk en niet-opzettelijk handelen is volgens de wetgever afhankelijk van de geschatte kans dat dieren gedood of verwond worden door het windpark, omdat onder opzet ook voorwaardelijk opzet valt. Dit betekent dat de minister zal beoordelen wat de kans is dat dieren worden gedood, onder andere op basis van de binding van een soort met het plangebied en het

35. Kamerstukken II 2014/15, 34058, 4, p. 3-4

36. Kamerstukken II 2014/15, 34058, 3, p. 17.

37. Kamerstukken II 2014/15, 34058, 3, p. 16.

38. Voor een schematisch overzicht van de verschillen tussen de verbodsbepalingen uit de Ffw, Habitatrichtlijn en Vogelrichtlijn verwijzen wij naar: F. Onrust \& A. Drahmann, Flora- en faunawet: nieuwe donkere wolken boven Nederland?, BR 2013/1 
gedrag van de soort (bijvoorbeeld de ligging van trekroutes en gebruikelijke vlieghoogte). ${ }^{39}$

De nu gekozen oplossing is voor de praktijk van groot belang, omdat voor de bouw en exploitatie van een windpark minder snel een ontheffing nodig zal zijn. ${ }^{40}$ Vanuit juridisch perspectief is echter sprake van een lapmiddel. Binnen de huidige tekst van de verbodsbepalingen wordt een kleine aanpassing gedaan om dichter bij de verbodsbepalingen van de richtlijnen te komen. Dichterbij, want er blijft een discrepantie tussen de formulering van de verbodsbepalingen in Europese en nationale context. Deze zal pas definitief worden opgelost met de inwerkingtreding van de Wet natuurbescherming. Bij de invoeringswetgeving van de Wet natuurbescherming zullen de gevolgen voor dit wetsvoorstel wel moeten worden betrokken.

Als toch een verbodsbepaling uit de Ffw wordt overtreden, kan de minister, op grond van artikel 7 , in het kavelbesluit zelf vrijstelling verlenen van de verbodsbepalingen. Er wordt dus geen aparte vrijstelling of ontheffing verleend. Dit past, volgens de memorie van toelichting, bij de beoogde geïntegreerde aanpak. ${ }^{41}$ Deze vrijstelling wordt, net als een Ffw-ontheffing, pas verleend als geen afbreuk wordt gedaan aan een gunstige staat van instandhouding van de desbetreffende soort en, indien sprake is van een strikt beschermde soort, er geen alternatieven zijn en een van de belangen wordt gediend die zijn opgenomen in de Ffw of in de richtlijnen. Volgens de wetgever blijkt uit het nationaal waterplan dat er geen bevredigende alternatieven zijn en wordt met de realisatie van windparken een aantal belangen gediend, namelijk 'volksgezondheid en openbare veiligheid', 'dwingende reden van groot openbaar belang' en 'werkzaamheden in het kader van ruimtelijke inrichting en ontwikkeling'. ${ }^{42}$

Ook aan een vrijstelling in het kavelbesluit kunnen voorschriften worden verbonden. Aandachtspunt hierbij is dat de verbodsbepalingen van de Ffw niet worden overtreden als mitigerende maatregelen kunnen worden getroffen. Als overtreding niet kan worden uitgesloten, dan kunnen (naast mitigerende ook) compenserende maatregelen worden voorgeschreven. In artikel 7 , lid 4 en 4 lid 1 onder $d$ wordt expliciet gesproken over de voorschriften die worden verbonden aan een eventuele vrijstelling. Als geen vrijstelling vereist is, zal het onder omstandigheden nog wel noodzakelijk zijn om een voorschrift over het treffen van mitigerende maatregelen op te nemen. De minister is hiertoe volgens ons op grond van artikel 4 wel bevoegd, maar het zou wenselijk zijn als de wetgever hieraan in de parlementaire geschiedenis nog aandacht zou besteden. Het opnemen van mitigerende maatregelen als voorschrift in het kavelbesluit is

39. Kamerstukken II 2014/15, 34058, 3, p. 39.

40. Hoewel de Afdeling in haar uitspraak van 3 oktober 2012, JM 2012/146 m.nt. L. Boerema, al rekening hield met de vraag of sprake was van 'wezenlijke invloed'.

41. Kamerstukken II 2014/15, 34058, 3, p. 18.

42. Kamerstukken II 2014/15, 34058, 3, p. 39-40 nodig, omdat op deze wijze de initiatiefnemer verplicht wordt de maatregelen te treffen.

Ten slotte wijzen wij erop dat door de monitoringsverplichtingen die aan het kavelbesluit worden verbonden het, volgens de memorie van toelichting, mogelijk is dat de aan de Ffw-vrijstelling verbonden voorwaarden worden versoepeld of verzwaard. ${ }^{43}$ Het gebruik van een dergelijk 'hand aan de kraan'-principe moet ons inziens weloverwogen gebeuren om te voorkomen dat initiatiefnemers worden geconfronteerd met vergaande gevolgen voor het project.

\section{Het aanwijzen en uitrollen van de windgebieden via het waterplan}

Hiervoor is al meerdere malen benoemd dat een kavelbesluit enkel betrekking kan hebben op gebieden in de Noordzee die daarvoor zijn aangewezen: de windgebieden. De aanwijzing van deze windgebieden gebeurt in het nationaal waterplan. Dit nationaal waterplan is een beleidsstuk op grond van de Waterwet. Weliswaar is dit beleidsstuk dus niet een voortvloeisel uit het wetsvoorstel voor windenergie op zee, maar voor de uitvoering van dit wetsvoorstel wel een essentieel onderdeel. Zonder de aanwijzing van de windgebieden kunnen namelijk geen kavelbesluiten worden genomen en in het nationaal waterplan zelf staan beleidsmatige kaders die doorspelen naar de kavelbesluiten. Daarom gaan wij hierna ook kort in op het nationaal waterplan.

De aanwijzing van de gebieden is thans gebeurd in eerst het Nationaal Waterplan 2009-2015 (hierna: waterplan 2015) en daarna aangevuld door de recent vastgestelde Rijksstructuurvisie Windenergie op Zee. Dit laatste document is een partiële herziening van het Waterplan 2015 (hierna: herziening). Hierna zal eerst worden ingegaan op de juridische status van het waterplan en vervolgens kort op de inhoud ervan.

\subsection{Juridische status van het waterplan}

Het waterplan heeft een dubbele juridische status. Ten eerste zijn de ministers van IenM en EZ verplicht om een nationaal waterplan vast te stellen op grond van artikel 4.1 van de Waterwet. In dit plan moeten de hoofdlijnen van het nationale waterbeleid en de daartoe behorende aspecten van het nationale ruimtelijke beleid worden opgenomen en in ieder geval het Noordzeebeleid bevatten. Het waterplan en de herziening vormen thans het nationaal waterplan in de zin van de Waterwet.

Ten tweede is het waterplan voor de ruimtelijke aspecten tevens een rijksstructuurvisie in de zin van de Wet ruimtelijke ordening (Wro).

43. Kamerstukken II 2014/15, 34058, 3, p. 37. 
Het waterplan is zowel op grond van de Waterwet als op grond van de Wro een beleidsstuk. Dat betekent dat de uitvoerende organen (in dit geval de ministers) dit beleid in acht moeten nemen. Afwijking van het beleid is in beginsel niet mogelijk. Andere, lagere bestuursorganen hoeven met het waterplan in beginsel slechts rekening te houden, hoewel via het Besluit algemene regels omgevingsrecht toch binding kan ontstaan. ${ }^{44}$

\subsection{De inhoud van het waterplan}

Het waterplan wijst de windgebieden aan waarbinnen de kavelbesluiten kunnen worden genomen. In het waterplan en in de herziening zijn elk twee gebieden aangewezen. Het betreft de volgende vier gebieden:

- 'Borssele';

- 'IJmuiden Ver';

- 'Hollandse Kust'; en

- 'Ten Noorden van de Waddeneilanden'.

Deze gebieden beslaan gezamenlijk een oppervlakte van $2900 \mathrm{~km}^{2}$, hetgeen bij een gemiddelde van $6 \mathrm{MW}$ per $\mathrm{km}^{2}$ resulteert in een potentieel windvermogen van 17.400 MW. Dit is dus veel meer dan de doelstelling van $4450 \mathrm{MW}$. De windgebieden zijn de uiterste grenzen waarbinnen eerst de kavelbesluiten en vervolgens de windvergunningen moeten worden gerealiseerd. De exacte locatie en omvang van de windparken zal afhangen van andere gebruiksfuncties en het mariene ecosysteem. Deze afstemming is al beleidsmatig ingevuld in het waterplan 2015, de herziening en de Beleidsnota Noordzee en zal bij de uitwerking van de kavelbesluiten een grote rol spelen. Daarom wordt op de belangrijkste afwegingen hierna nader ingegaan.

Zoals hiervoor al gesteld, vindt er in de Noordzee veel verschillend gebruik plaats, zoals de winning van gas en olie, visserij, oefengebieden voor defensie, zandwinning, recreatie en toerisme en uiteraard scheepvaartroutes. De Noordzee vormt ook een zeer complex en open marien ecosysteem. ${ }^{45}$ Het toevoegen van nog een functie, bijvoorbeeld grootschalige windparken, dient daarom weloverwogen te gebeuren.

Het waterplan 2015 schrijft voor dat in de ruimtelijke afweging van het gebruik van de Noordzee prioriteit wordt gegeven aan activiteiten die van nationaal belang zijn voor Nederland. Duurzame (wind)energie is een dergelijk nationaal belang. Hetzelfde geldt voor olie- en gaswinning, scheepvaart en zandwinning en -suppletie. In gebieden die zijn aangewezen voor activiteiten van nationaal belang mogen andere activiteiten zonder nationaal belang dit gebruik niet belemmeren. Bij stapeling van nationale belangen in één gebied wordt er gestreefd naar gecombineerd en ruimte-efficiënt gebruik, mits het oorspronkelijke gebruik niet onevenredige schade of hinder ondervindt. Verder gelden bij de afstemming van het ruimtegebruik de randvoorwaarden zoals opgeno-

44. Kamerstukken I/ 2002/03, 28916, 3, p. 14-15; zie verder E.M.N. Noordover, SVIR en Barro: beleid en regel voor de nationale ruimte, BR 2012/49.

45. Rijksstructuurvisie Windenergie op Zee, p. 13. men in het beleid. Voor het beleidsmatig aanwijzen van de windgebieden voor windparken zijn in het waterplan 2015 enkele vertrekpunten geformuleerd. Dit betreft de prioritering van de hiervoor genoemde nationale belangen en het eveneens al genoemde evenwicht tussen efficiënt en veilig gebruik van de Noordzee met het mariene ecosysteem.

Voor de verdere invulling van de windgebieden in de kavelbesluiten bevatten het nationaal waterplan en de herziening waardevolle informatie. Dit betreft enerzijds algemene beleidsuitgangspunten en anderzijds specifieke onderwerpen per windgebied.

De algemene beleidsuitgangspunten betreffen onder meer de afstemming tussen de gebruiksfuncties van de Noordzee voor windenergie enerzijds en scheepvaartroutes, mijnbouw en leidingen en kabels anderzijds. Deze laatste drie gebruiksfuncties leggen thans al beslag op het ruimtegebruik en bij het opstellen van kavelbesluiten moet nog verder worden bepaald welke afstanden aangehouden moeten worden tussen nieuwe windparken en de bestaande gebruiksfuncties. Voor deze afweging worden beleidsmatige kaders opgesteld. Ten eerste het 'Afwegingskader voor veilige afstanden tussen scheepvaartroutes en windparken op zee'. Dit afwegingskader is bedoeld om de ruimte tussen de scheepvaartroutes en windparken op zee te kunnen bepalen. Met het afwegingskader wordt de mogelijkheid van maatwerk geboden in plaats van het vasthouden aan een zone van twee nautische mijlen tussen scheepvaartroutes en windparken. Ten tweede het 'Afwegingskader Mijnbouw en Windenergie op zee'. Dit afwegingskader gaat meer helderheid verschaffen over de wijze waarop maatwerk kan worden toegepast bij de bepaling van de aanvaardbare afstanden tussen mijnbouwinstallaties en windparken. Het afwegingskader wordt opgesteld in overleg met onder meer de olie- en gassector. De uitkomst hiervan wordt opgenomen in een actualisatie van het Waterplan 2015 en de Beleidsnota Noordzee. Ten slotte een afwegingskader voor leidingen en kabels in de zeebodem. Voor kabels en leidingen geldt een veiligheidszone van 500 meter, waarbinnen geen activiteiten in de bodem mogen plaatsvinden. Voor de tracés voor nieuwe kabels en leidingen wordt gekeken naar het zo veel mogelijk bundelen van de nieuwe tracés met al bestaande tracés. Ook worden de nieuwe kabels en leidingen zelf zo veel mogelijk gebundeld. De bundeling beoogt het ruimtebeslag van kabels en leidingen tot een minimum te beperken ten behoeve van de andere ontwikkelingen in de Noordzee. ${ }^{46}$

Deze afwegingskaders zullen in acht moeten worden genomen bij de vaststelling van kavelbesluiten. Daarbij moet ook nog afstemming plaatsvinden tussen de beoogde windparken en het maritieme ecosysteem. Voor de benutting en begrenzing van mogelijke locaties binnen de windgebieden moet nog nader onderzoek worden gedaan naar de ecologische effecten, mede ten behoeve

46. Zie ook Rijksstructuurvisie Windenergie op Zee, p. 18-19 
van de noodzakelijke maatregelen, voorwaarden dan wel beperkingen vanwege deze effecten. Voor de beoordeling van de cumulatieve effecten komt er ook nog een te ontwikkelen kader 'Ecologie en Cumulatie' en wordt een ecologisch toetsingskader ontwikkeld om te beoordelen of significante effecten van de windparken te verwachten zijn. Op basis van dit toetsingskader zullen de benodigde voorschriften worden verbonden aan de kavelbesluiten om eventueel optredende significante effecten te voorkomen. ${ }^{47}$

Andere aandachtspunten per windgebied zijn in de plan-MER's voor Hollandse Kust en Ten Noorden van de Waddeneilanden geformuleerd. Dit betreft de ecologie en zicht en beleving voor het windgebied 'Hollandse Kust'. Voor het windgebied 'Ten Noorden van de Waddeneilanden' zijn de aandachtspunten wederom ecologie en de netaansluiting op het land. ${ }^{48}$ Deze aandachtspunten moeten dus worden meegenomen in de kavelbesluiten.

Het voorgaande toont het belang van een zorgvuldige afweging en motivering bij het vaststellen van de kavelbesluiten en zal in belangrijke mate bepalend zijn voor de ruimte die wordt gevonden voor windparken op zee.

\subsection{Geplande uitrol van de windparken en de} taak van de netbeheerder hierbij

De windparken zullen gefaseerd worden gerealiseerd. De belangrijkste reden om te kiezen voor deze gefaseerde uitrol is de verbinding van de windparken met het elektriciteitsnetwerk op het land. De realisatie van een windpark op de Noordzee is duur en naarmate een windpark verder van de kust wordt gerealiseerd, stijgen de kosten. Dit wordt onder meer veroorzaakt door de noodzakelijke aanleg van de bekabeling naar het elektriciteitsnetwerk op het land. De tot nu toe gebouwde windparken zijn aangelegd met een eigen elektriciteitskabel. Voor de toekomstige parken is het, volgens de minister, beter om te kiezen voor een gecoördineerde netaansluiting van de te realiseren windparken op zee, omdat dit leidt tot lagere maatschappelijke kosten en een kleinere impact op de leefomgeving. ${ }^{49}$ Daarom heeft de minister (1) een gefaseerde uitrol gepland en (2) wordt TenneT aangewezen als netbeheerder op zee.

De gefaseerde uitrol ziet er als volgt uit. Als eerste zal het windgebied 'Borssele' worden ontwikkeld en daarna de 'Hollandse Kust' ${ }^{50}$ De belangrijkste reden om met 'Borssele' te beginnen is dat op deze locatie al gewerkt wordt aan een noodzakelijke verzwaring van het landelijk elektriciteitsnet, waardoor de aansluiting op land eenvoudiger te realiseren is. ${ }^{51}$ Wij gaan er dan ook van uit dat de eerste kavelbesluiten zullen worden genomen voor 'Borssele'.

\footnotetext{
7. Rijksstructuurvisie Windenergie op Zee, p. 11 en 34

8. Rijksstructuurvisie Windenergie op Zee, p. 29 en 31.

. Kamerstukken II 2013/14, 31510, 49, p. 2.

Kamerstukken II 2013/14, 33561, 11, p. 3.

Kamerstukken II 2013/14, 31510, 49, p. 11
}

Met de aanwijzing van TenneT als netbeheerder voor het elektriciteitsnet op zee wordt vooral de economische uitvoerbaarheid van windparken op zee gediend. Deze aanwijzing is aangekondigd bij Kamerbrief van 18 juni $2014 .{ }^{52}$ Hiervoor is echter een wetswijziging van de Elektriciteitswet 1998 nodig. Deze wijziging vindt deels plaats in de wet en deels in een toekomstige wijziging van de Elektriciteitswet 1998.

TenneT krijgt via een toevoeging aan artikel 16 lid 2 van de Elektriciteitswet 1998 de taak om de aanleg van het net op zee voor te bereiden (zie art. 31 van het wetsvoorstel). Om eerder met de voorbereidingstaken te kunnen starten dan de datum van inwerkingtreding van dit wetsvoorstel, is ervoor gekozen om de kosten die TenneT makt vanaf het moment van ondertekening van het Energieakkoord op 6 september 2013 op te nemen in de tarieven die TenneT in rekening mag brengen. ${ }^{53}$

De taak om het net op zee aan te leggen en te beheren en de toewijzing van deze taak aan Tenne $\mathrm{T}$ worden verder opgenomen in de integrale herziening van de Elektriciteitswet 1998. Deze wijziging is onderdeel van de wetgevingsagenda STROOM. Het is echter de verwachting dat het wetsvoorstel eerder wordt aangenomen dan STROOM. Door nu al een deel van de taken op te nemen in de wet kan eerder worden begonnen met de noodzakelijke uitbreidingen van het elektriciteitsnet, zodat de aansluitingen voor de windparken hopelijk tijdig gereed zijn. ${ }^{54}$

\section{De windvergunning}

Met het kavelbesluit alleen kan nog geen windpark worden gerealiseerd. Hiervoor moet aan een initiatiefnemer een windvergunning worden verleend. Artikel 12 bepaalt namelijk dat het verboden is om zonder vergunning een windpark op zee te bouwen of te exploiteren. Hoofdstuk 3 van het wetsvoorstel betreft de windvergunning. Hierna zal eerst de inhoud van de windvergunning worden geschetst (par. 5.1). Daarna zal worden ingegaan op de wijze van totstandkoming van de vergunning (par. 5.2). Ten slotte zal nog iets worden gezegd over het inrichtingsplan (par. 5.3).

\subsection{Inhoud van de windvergunning}

Een windvergunning geeft een initiatiefnemer het alleenrecht om op een bepaalde locatie een windpark te mogen bouwen en exploiteren. De minister verleent geen vergunning voor de aanleg van een windpark dat buiten een kavel, zoals aangewezen in het kavelbesluit, is gelegen. Dit volgt uit artikel 13 aanhef en onder a.

Daarnaast bevat artikel 14 een zestal algemene, facultatieve weigeringsgronden, bijvoorbeeld dat aannemelijk moet zijn dat de aanleg van het windpark uitvoerbaar en

52. Kamerstukken // 2013/14, 31510, 49

53. Kamerstukken II 2014/15, 34058, 3, p. 20.

54. Kamerstukken II 2014/15, 34058, 3, p. 21. 
technisch en financieel haalbaar is. Deze relatief open normen kunnen op grond van het tweede lid worden uitgewerkt bij ministeriële regeling. Hierbij kan worden gedacht aan zowel concrete materiële normen (bijvoorbeeld een concrete eis met betrekking tot het eigen vermogen van de aanvrager of de creditrating van de aanvrager) als hoe procesmatig kan worden aangetoond dat aan een eis is voldaan (bijvoorbeeld een procesmatige eis aan de aanvrager die door middel van een verklaring van een onafhankelijke deskundige aantoont dat het ontwerp technisch haalbaar is). De eis dat de bouw en exploitatie van een windpark uitvoerbaar moeten zijn, is een basiseis die fungeert als vangnet en als versterking van de overige criteria. ${ }^{55}$

Bijzondere aandacht verdient nog de weigeringsgrond van artikel 14 lid 1 onder d. Dit onderdeel bepaalt dat een vergunning slechts kan worden verleend als voldoende aannemelijk is dat de bouw en exploitatie van het windpark 'gestart kan worden binnen vier jaar na de datum waarop de vergunning onherroepelijk is geworden'. Ons is onduidelijk of daarmee wordt gedoeld op de start van de bouw of de start van de exploitatie. In de memorie van toelichting wordt, onder verwijzing naar het Energieakkoord, echter gesteld dat het uitgangspunt is dat een windpark binnen vier jaar na het verkrijgen van een subsidiebeschikking operationeel is. ${ }^{56}$ Het lijkt dan ook logisch dat artikel 14 lid 1 onder d refereert aan de start met de exploitatie. Het lijkt ons wenselijk om de wettekst hierop aan te passen.

Als een aanvraag voor een windvergunning door meer dan één (rechts)persoon wordt ingediend, bijvoorbeeld een consortium, dan worden deze (rechts)personen gezamenlijk als vergunninghouder beschouwd. De windvergunning is op grond van artikel 16 lid 1 alleen overdraagbaar met schriftelijke toestemming van de minister. Als een van de (rechts)personen zijn aandeel in de vergunning wil overdragen, is hiervoor op grond van artikel 18 ook toestemming van de minister nodig. Als de minister niet tijdig, dat wil zeggen binnen acht weken, ${ }^{57}$ reageert op een aanvraag om toestemming voor een overdracht, is de toestemming van rechtswege verleend. Dit volgt uit artikel 16 lid 3, dat paragraaf 4.1.3.3 Awb van toepassing verklaart.

Daarnaast wordt in een windvergunning bepaald voor welk tijdvak de vergunning geldt. Dit tijdvak moet passend zijn bij de te verwachten levensduur van een windpark op die locatie, maar is ten hoogste dertig jaar, aldus artikel 15. Ook wordt in een windvergunning bepaald binnen welke tijdvakken de in de vergunning aangegeven activiteiten moeten worden verricht. Voor verschillende stappen in de bouw kunnen verschillende tijdvakken worden vastgesteld, waaronder het aanbrengen van de fundatie, het plaatsen van de turbines en het leggen

55. Kamerstukken II 2014/15, 34058, 3, p. 42-43

56. Kamerstukken II 2014/15, 34058, 3, p. 4.

57. Het wetsvoorstel bevat geen afwijkende beslistermijn voor deze aanvraag, waardoor de redelijke termijn van art. 4:13 lid 2 Awb van toepassing is. van de aansluitkabel. ${ }^{58}$ Voorgaande vergaande invulling van het gebruik in de tijd van de windvergunning kan belemmerend werken voor initiatiefnemers. De tijdvakken in de windvergunning moeten wel afdoende rekening houden met onbekendheden of tegenvallers in de planning van initiatiefnemers, mede vanwege mogelijke handhavingsbevoegdheden indien tijdvakken niet worden gehaald.

Als de activiteiten waarvoor de vergunning geldt niet langer worden uitgevoerd, kan de vergunning op grond van artikel 17 lid 1 onder b worden gewijzigd of ingetrokken. Daarnaast is het op grond van artikel 15 lid 5 verboden om te handelen in strijd met de vergunning en de daaraan verbonden voorwaarden en voorschriften. Als dit verbod wordt overtreden, is de minister op grond van artikel 27 bevoegd om een last onder dwangsom of bestuursdwang op te leggen.

Met de hiervoor genoemde beperking van de looptijd van de windvergunning beoogt de wetgever de belangen van andere - zowel bestaande als toekomstige - gebruikers van de Noordzee te beschermen. De wetgever acht het niet wenselijk dat een vergunninghouder voor onbeperkte tijd een locatie op zee in gebruik kan hebben, omdat de ruimte voor wind op zee en voor ander gebruik schaars is. Op het moment dat een vergunning afloopt, zal een nieuw kavelbesluit kunnen worden genomen, waarna een nieuwe tender voor de windvergunning kan volgen. Deze nieuwe tender is ook mogelijk omdat, anders dan bij windparken op land, op zee geen sprake is van eigendom van de zeebodem of de waterkolom door de vergunninghouder. ${ }^{59}$

Een interessante vraag is wat de juridische kwalificatie van de windvergunning is. Hoewel het wetsvoorstel spreekt van een 'vergunning', zou men zich kunnen afvragen of niet (ook) sprake is van een 'concessie'. Het gaat de reikwijdte van dit artikel te buiten om hier uitgebreid op in te gaan, maar bij een concessie is sprake van de verlening van een alleenrecht. Een reguliere vergunning is normaliter geen concessie, omdat die uitsluitend een bepaalde handeling toestaat en geen alleenrecht verleent. In deze wet is echter wel sprake van het verlenen van een alleenrecht: maar één initiatiefnemer zal een windpark kunnen bouwen en exploiteren en deze initiatiefnemer is bovendien niet de eigenaar van de zeebodem. Een ander belangrijk element van een concessie is dat sprake moet zijn van een bezwarende titel, oftewel van een uitvoeringsplicht. Een initiatiefnemer zal op grond van de windvergunning verplicht zijn om (binnen een bepaalde termijn) het windpark te bouwen en in gebruik te nemen. Aangezien het verboden is om in strijd te handelen met de voorschriften van de vergunning en dus het bouwen en in gebruik nemen afgedwongen zouden kunnen worden, is het volgens ons verdedigbaar dat sprake is van een concessie. Hier komt nog bij dat de windvergunning tegelijk met de subsidie zal

58. Kamerstukken II 2014/15, 34058, 3, p. 43.

59. Kamerstukken II 2014/15, 34058, 3, p. 43. 
worden verleend en op grond van de huidige subsidieregeling een subsidie-uitvoeringsovereenkomst (met boeteclausule) wordt gesloten. ${ }^{60}$ De kwalificatie als concessie kan van belang zijn, omdat onder omstandigheden een concessie aanbestedingsplichtig kan zijn. ${ }^{61}$ Het is dan ook opvallend dat in de memorie van toelichting het woord 'concessie' geen enkele keer voorkomt. Het is wenselijk dat de wetgever tijdens de parlementaire behandeling ingaat op de vraag in hoeverre sprake is van een concessie, waar bij de verlening het Europese aanbestedingsrecht in acht moet worden genomen, al was het maar om eventuele discussie in de praktijk hierover voor te zijn.

\subsection{Wijze van totstandkoming (tendering) en rechtsbescherming}

De minister verleent op grond van artikel 13 aanhef en onder $b$ van het wetsvoorstel geen vergunning aan een windpark als voor een kavel al eerder een vergunning is verleend. Dat is ook logisch, want er passen natuurlijk niet meerdere windparken op één locatie. ${ }^{62}$ De vraag is dan wel aan wie die ene vergunning verleend moet worden. De wetgever heeft gekozen voor een systeem van tendering, waarbij - kort gezegd - eenieder een aanvraag kan indienen en de vergunning wordt verleend aan degene met de 'beste' aanvraag.

In het wetsvoorstel zijn hiervoor twee procedures opgenomen, namelijk één voor de situatie dat naast de vergunning ook subsidie voor de realisatie van windparken op zee nodig is (par. 3.2 van het wetsvoorstel) en één voor de situatie dat geen subsidie meer nodig is (par. 3.3 van het wetsvoorstel).

Hierna zal meer in detail worden ingegaan op beide procedures, nadat eerst enkele algemene opmerkingen zijn gemaakt die gelden voor beide procedures.

\subsubsection{Algemeen}

Hiervoor is al ingegaan op de algemene weigeringsgronden die zijn opgenomen in artikel 14. In het kader van een tenderprocedure is van belang dat dit minimumeisen zijn. Als aan deze eisen niet voldaan wordt, moet de aanvraag worden afgewezen. Deze minimumeisen zijn dus als ingangseisen te onderscheiden van de rangschikkingscriteria.

In de memorie van toelichting staat dat een tenderprocedure één kavel of meerdere kavels kan omvatten. Als er meerdere kavels beschikbaar zijn, kunnen aanvragers een aanvraag voor één of meerdere kavels indienen. Benadrukt wordt dat het niet op voorhand is uitgesloten dat in één tenderprocedure of in opeenvolgende tenderprocedures meerdere windvergunningen aan dezelfde aanvrager worden verleend, maar in zo'n geval wordt

60. Zie voor meer hierover ook A. Drahmann, Uitdijing van de werking van het transparantiebeginsel: van concessies naar vergunningen? Een beschouwing naar aanleiding van het Betfair-arrest, NTB 2012/25.

61. Naast de Aanbestedingswet 2012 wijzen wij in dit verband ook op Richtlijn 2014/23/EU (de Concessierichtlijn), die op 18 april 2016 in Nederland moet zijn geïmplementeerd.

62. Zie ook Kamerstukken II 2014/15, 34058, 3, p. 42 wel beoordeeld of deze marktpartij meerdere windparken tegelijkertijd kan realiseren en met name financieren. ${ }^{63}$

Daarnaast is van belang dat met het opstellen van het kavelbesluit door de minister en alle daaraan ten grondslag liggende onderzoeken kosten zijn gemoeid. Het wetsvoorstel bepaalt dat in het kavelbesluit kan worden vastgelegd hoe hoog deze kosten zijn, waarna deze kosten te verhalen zijn. Het te verhalen bedrag kan per kavelbesluit verschillen, omdat het afhankelijk is van het aantal onderzoeken dat noodzakelijk is voor het nemen van het kavelbesluit en de zwaarte van die onderzoeken. De kosten kunnen op grond van artikel 10 worden verhaald op de vergunninghouder. De reden van de wetgever hiervoor is dat de vergunninghouder ook degene is die uiteindelijk baat heeft bij de gedane onderzoeken. Zolang nog subsidie voor het realiseren van een windpark is vereist, zal in het kavelbesluit het te betalen bedrag op $€ 0$ worden vastgesteld. Vanuit subsidieoogpunt is het namelijk, aldus de memorie van toelichting, duur om de kosten in rekening te brengen bij de uiteindelijke subsidieontvanger, omdat kosten die aan het begin van de subsidiabele periode worden gemaakt, over de gehele subsidielooptijd worden verdeeld en daarmee het basisbedrag verhogen. ${ }^{64}$

Ongeacht het wel of niet verlenen van subsidie is de beslistermijn voor de minister op grond van artikel 21 dan wel 25 dertien weken, welke termijn eenmalig met dertien weken kan worden verlengd.

Tegen het verlenen van de windvergunning staat op grond van artikel 30 aanhef en onder 3 beroep open bij het College van Beroep voor het bedrijfsleven $(\mathrm{CBb})$. Hiermee wordt aangesloten bij de huidige situatie, waarbij het $\mathrm{CBb}$ bevoegd is te oordelen over beroepen gericht tegen subsidiebesluiten op grond van de Kaderwet EZ. ${ }^{65}$ Dit heeft wel een versnippering van de rechtsbescherming tot gevolg: de Afdeling beoordeelt het kavelbesluit en het $\mathrm{CBb}$ de windvergunning. Deze versnippering vinden wij ongelukkig. Bovendien zullen geschillen over windvergunning niet alleen betrekking hebben op de rangschikking, maar ook op milieu- en ruimtelijke aspecten, zoals de vraag of de vergunning past binnen het kader van het kavelbesluit (en de daaronder liggende passende beoordeling en Ffw-vrijstelling) en het nationaal waterplan. Voorheen lag de rechtsbescherming tegen de watervergunningen voor windparken op zee bij de Afdeling, waarmee de Afdeling dus ervaring heeft in deze zaken. In het nu voorgestelde systeem moet het $\mathrm{CBb}$ zich ook uitlaten over de milieu- en ruimtelijke aspecten, terwijl dergelijke onderwerpen zelden bij het $\mathrm{CBb}$ ter beoordeling liggen. Het had dan ook onze voorkeur gehad als de Afdeling bevoegd zou zijn te beslissen over zowel het kavelbesluit

63. Kamerstukken II 2014/15, 34058, 3, p. 19.

64. Kamerstukken II 2014/15, 34058, 3, p. 41.

65. Kamerstukken II 2014/15, 34058, 3, p. 48. 
als de windvergunning, temeer als straks geen subsidie meer voor windparken op zee nodig is.

\subsubsection{Vergunningverlening zonder subsidie}

Als er geen subsidie voor de bouw en exploitatie van een windpark (meer) nodig is, zal de rangschikking van de aanvragen om een windvergunning geschieden aan de hand van de criteria die in artikel 24 lid 2 zijn opgenomen. Deze criteria hebben onder meer betrekking op de capaciteit van het windpark, de kennis en ervaring van de aanvrager en de kwaliteit van het ontwerp van het windpark. Deze criteria zijn nog erg ruim en behoeven nadere concretisering. In de memorie van toelichting wordt aangegeven dat bij de kwaliteit van het ontwerp van het windpark kan worden gedacht aan de vraag in welke mate het ontwerp van het windpark de effecten op andere belangen, zoals natuur, visserij, scheepvaart of olie- en gaswinning, beperkt. ${ }^{66} \mathrm{Bij}$ ministeriële regeling zullen regels worden gesteld over de onderlinge weging van de rangschikkingscriteria. Ten behoeve van de beoordeling van de aanvragen schrijft artikel 23 ook voor wat er ten minste in de aanvraag dient te worden opgenomen.

\subsubsection{Vergunningverlening met subsidie}

Zolang subsidie nodig is voor het realiseren van windparken op zee, valt de windvergunningverlening samen met de procedure voor de subsidieverlening, omdat het ongewenst is als beide procedures tot een andere 'winnaar' zouden leiden.

De regeling in het wetsvoorstel is kort, omdat de regeling uit de Kaderwet EZ-subsidies ${ }^{67}$ en het Besluit stimulering duurzame energieproductie (Besluit SDE) leidend zijn. Om de afspraken uit het energieakkoord te kunnen realiseren zal een nieuwe subsidieregeling worden opgesteld en zal waar nodig ook het Besluit SDE worden aangepast. ${ }^{68}$ In april 2014 is een concept voor het Besluit tot wijziging van het Besluit SDE ter consultatie gelegd. ${ }^{69}$ Hierna zal eerst kort op de regeling in het wetsvoorstel worden ingegaan en vervolgens op het conceptbesluit.

\section{- De regeling in het wetsvoorstel}

De aanvraag voor de windvergunning moet op grond van artikel 20 worden ingediend in de periode waarin ook de subsidieaanvraag ingediend moet worden. Er is dus sprake van twee aparte aanvragen, maar aan de aanvraag voor de vergunning worden geen andere eisen gesteld dan aan de subsidieaanvraag. Op de vergunningaanvraag wordt ook gelijktijdig met de subsidieaanvraag besloten. Aan het doen van een aanvraag zijn kosten ver-

66. Kamerstukken II 2014/15, 34058, 3, p. 20.

67. Art. 3 van de Kaderwet EZ-subsidies vormt de wettelijke grondslag voor de SDE-subsidieverlening.

68. Kamerstukken II 2014/15, 34058, 3, p. 48 en Kamerstukken II 2013/14, 31239, 171, p. 3-4.

69. Het conceptbesluit, de concepttoelichting en de ingediende reacties zijn te vinden op: <www.internetconsultatie.nl/sde>. bonden voor de aanvrager (leges) met als doel om 'alleen serieuze partijen een aanvraag te laten indienen'. ${ }^{70}$

Als meerdere aanvragen voldoen aan de minimumeisen (art. 14) en indieningseisen (art. 20) zal, op grond van artikel 21, vervolgens een selectie plaatsvinden via de selectiecriteria van de subsidieregeling. Daarbij merken wij terzijde op dat het ons bevreemdt dat in de toelichting bij artikel 21 wordt ingegaan op zowel selectie door middel van een rangschikking van de aanvragen als selectie door middel van verdeling op volgorde van binnenkomst. ${ }^{71}$ Deze verlening op volgorde van binnenkomst wordt immers juist als een van de knelpunten van het huidige systeem gezien.

- Het conceptbesluit

Kern van de wijziging van het besluit is dat er bij een subsidietender geen sprake meer zal zijn van concurrentie tussen verschillende locaties (waarvoor een watervergunning was verleend), maar van concurrentie om een specifieke locatie. $^{72}$

Zoals eerder al gesteld, wordt het mogelijk dat één aanvrager voor meerdere locaties een subsidieaanvraag indient. In dat geval dient voor elke locatie afzonderlijk een tenderbedrag te worden opgegeven. ${ }^{73}$ In het conceptbesluit staat dat de gecombineerde aanvraag wordt behandeld als één aanvraag. Het is de vraag wat hiermee precies bedoeld wordt en in hoeverre in dat geval in de gecombineerde aanvraag rekening kan worden gehouden met synergievoordelen. ${ }^{74}$

Daarnaast acht de minister het wenselijk om voor de subsidiëring van windenergie op zee een maximale productie in $\mathrm{kWh}$ per locatie, of voor meerdere locaties tezamen, te kunnen vaststellen. Een dergelijk maximum geeft, aldus de toelichting, de mogelijkheid om een hoog maximumaantal vollasturen vast te stellen zonder dat er overstimulering plaatsvindt. ${ }^{75}$

Op grond van artikel 2 van het (huidige) Besluit SDE wordt bij ministeriële regeling de wijze van verdeling bepaald. Gelet op de doelstellingen van het wetsvoorstel gaan we ervan uit dat gekozen zal worden voor verdeling op volgorde van rangschikking. In dat geval zijn artikel 17 e.v. van het Besluit SDE van belang. Artikel 60 lid 1 van het Besluit SDE zal na de wijziging door het conceptbesluit bepalen dat de minister de aanvragen rangschikt zodanig dat een aanvraag hoger wordt gerangschikt indien: (a) voor hernieuwbare elektriciteit, hernieuwbaar gas of hernieuwbare warmte het tenderbedrag per $\mathrm{kWh}$ lager is, (b) er meer sprake is van technologische of brandstofinnovatie, en (c) voor de productie van hernieuwbare elektriciteit, hernieuwbaar gas of hernieuwbare warmte sprake is van meer netto-broeikasgas-

70. Kamerstukken II 2014/15, 34058, 3, p. 45.

71. Kamerstukken II 2014/15, 34058, 3, p. 45.

72. P. 12 van het conceptbesluit met toelichting.

73. Art. I onderdeel P (art. 19) van het conceptbesluit.

74. Zie tevens de zienswijzen van Dong Energy en Essent/RWE op <www. internetconsultatie.nl/sde/reacties>

75. Art. B (art. 2 lid 6) van het conceptbesluit. 
reductie ten opzichte van de productie van energie uit niet-hernieuwbare bronnen. De wegingsfactoren en toepassing van de criteria kunnen bij ministeriële regeling worden vastgesteld.

- $\quad$ Een wijziging of nieuwe regeling?

Er is nog geen concept voor een wijziging van de Regeling windenergie op zee 2009 of een geheel nieuwe Regeling windenergie op zee 2015 openbaar gemaakt. Het is dan ook nog niet mogelijk om aan te geven hoe de subsidietendering concreet zal worden uitgewerkt.

Wel wijzen wij op een belangrijk element uit de huidige regeling, waarvan de vraag is of, en zo ja, in hoeverre dit wordt voortgezet, en dat is de uitvoeringsovereenkomst. Artikel 6 van de regeling bepaalt dat een subsidieverleningsbeschikking wordt verleend onder de opschortende voorwaarde dat een uitvoeringsovereenkomst wordt gesloten. De tekst van deze overeenkomst is opgenomen in bijlage 2 bij de regeling. Artikel 3 van deze overeenkomst bepaalt dat de ondernemer een bankgarantie moet afgeven. Ook in de memorie van toelichting bij het wetsvoorstel wordt opgemerkt dat aan subsidieverlening eventuele financiële garanties zullen worden verbonden die te maken hebben met het ook daadwerkelijk realiseren van het windpark waarvoor subsidie is verleend. ${ }^{76}$ Daarnaast bevat artikel 5 van de uitvoeringsovereenkomst een aantal boetebepalingen die betrekking hebben op de aanvang van de bouw. Gelet op het grote belang dat de uitvoeringsovereenkomst heeft in het kader van de handhaving via de garanties en boetes, lijkt het aan te raden de uitvoeringsovereenkomst te handhaven.

Verder vragen wij ons af in hoeverre de rangschikkingscriteria voor subsidieverlening nog zullen worden gewijzigd in de regeling. Het lijkt er namelijk op dat de factoren die de wetgever van belang acht voor de rangschikking van de windvergunning afwijken van de subsidierangschikkingscriteria. De capaciteit van het windpark (hoeveel kWh kan worden gerealiseerd) is in ieder geval bij beide een criterium, maar de kwaliteit van het ontwerp van het windpark lijkt vooralsnog geen rol te spelen bij de subsidieverlening. $\mathrm{Nu}$ de verlening van een subsidie automatisch leidt tot verlening van een windvergunning, lijkt het ons noodzakelijk dat in het kader van de subsidieverlening (ook) wordt gekeken naar bijvoorbeeld de vraag in welke mate het ontwerp van het windpark de effecten op andere belangen, zoals natuur, visserij, scheepvaart of olie- en gaswinning, beperkt. ${ }^{77}$ Daarnaast vragen wij ons af in hoeverre de aanvraag om een vergunning met subsidie dezelfde informatie moet bevatten als een vergunning zonder subsidie. Ervan uitgaande dat artikel 23 geen onnodige informatie vraagt voor vergunningverlening zonder subsidie, zal dit dus ook voor de vergunning met subsidie noodzakelijke informatie zijn. Ons inziens had het de voorkeur verdiend om dit ook voor de vergunningverlening met subsidie in het wetsvoorstel vast te leggen, maar in ieder geval zou dit duidelijk uit de wetsgeschiedenis moeten volgen dan wel geborgd kunnen worden in de subsidieregelgeving.

In het verlengde van het voorgaande vragen wij ons meer in het algemeen af waarom de windvergunning de subsidie volgt. Waarom heeft de wetgever er niet voor gekozen dit om te draaien? In dat geval vraagt een initiatiefnemer een windvergunning aan en geeft hij daarbij aan hoeveel geld (subsidie) hij nodig heeft om het alleenrecht (de bouw en exploitatie van het windpark) uit te kunnen oefenen. De hoogte van het gevraagde bedrag heeft dan - net als de overige criteria - gevolgen voor de rangschikking van de aanvragen om een windvergunning. Op deze wijze worden de voorwaarden waaronder de activiteit (het realiseren van een windpark) mag worden verricht, centraal gesteld in plaats van de financiële aspecten van die activiteit.

\subsection{Het inrichtingsplan}

Ten slotte nog een korte opmerking over het inrichtingsplan. Dit inrichtingsplan wordt uitsluitend genoemd in de memorie van toelichting en niet in het wetsvoorstel. Het inrichtingsplan volgt pas na de vergunningverlening en voorafgaand aan de bouw. Door middel van het inrichtingsplan laat de initiatiefnemer aan het bevoegd gezag (in de memorie van toelichting 'de handhaver' genoemd) zien dat het windpark gebouwd gaat worden overeenkomstig de gestelde voorwaarden in het kavelbesluit. Dit inrichtingsplan is niet appellabel. ${ }^{78}$ Aangezien deze figuur niet terugkomt in het wetsvoorstel zelf, nemen wij vooralsnog aan dat hier sprake is van een aan de windvergunning te verbinden voorschrift.

\section{Afronding}

Met het wetsvoorstel beoogt de wetgever op korte termijn windparken op zee te kunnen realiseren. Het wetsvoorstel introduceert een aantal nieuwe rechtsfiguren waarmee dit doel bereikt moet worden. Twee aspecten zijn ons inziens daarbij in het bijzonder van belang. Het eerste aspect is dat de minister ten behoeve van het kavelbesluit de benodigde onderzoeken zal verrichten, waardoor de onderzoeklasten niet meer op iedere initiatiefnemer zelf rusten. De getrapte werkwijze van een kavelbesluit, dat de buitenste bandbreedten vastlegt, naar een windvergunning leidt er ook toe dat de kaders bij vergunningverlening duidelijk zijn zonder verlies van de nodige flexibiliteit bij de realisatie door de initiatiefnemers. Het tweede aspect is dat de windvergunning (al dan niet met subsidie) niet wordt verleend op volgorde van binnenkomst van de aanvragen, maar op basis van een kwalitatieve toets (tender). Hierdoor worden initiatiefnemers uitgedaagd om zo veel mogelijk $\mathrm{kWh}$ te realiseren tegen zo min mogelijk subsidie en een zo laag 
mogelijke belasting voor onder andere derden en de natuur.

Het wetsvoorstel is daarmee een stap in de goede richting. Bij het lezen van het wetsvoorstel en de toelichting kwam echter nog wel een aantal vragen op die wellicht nog meegenomen kunnen worden in de behandeling van het wetsvoorstel in de Tweede Kamer. De belangrijkste vijf zijn de volgende.

Ten eerste is het van groot belang dat de buitenste contouren (de bandbreedte) van de onderzoeken die ten grondslag liggen aan het kavelbesluit (met name het MER en de passende beoordeling) afdoende zijn en dat er weinig tijdsverloop is tussen het vaststellen van het kavelbesluit en de windvergunningverlening. Het zou onnodig vertragend zijn als het kavelbesluit gewijzigd zou moeten worden door tijdsverloop of door andere ontwikkelingen waardoor het te realiseren windpark niet meer past binnen de kaders van het kavelbesluit en de onderliggende onderzoeken.

Ten tweede zijn er vraagtekens te plaatsen bij de regeling voor het MER voor het kavelbesluit. Het is namelijk niet de bedoeling van de wetgever om de windvergunning (naast het kavelbesluit) aan te wijzen als een m.e.r.-(beoordelings)plichtig besluit. Het kavelbesluit wordt vervolgens aangewezen als project-MER-plichtig. De wetgever dient echter nog nader te onderbouwen waarom (1) het kavelbesluit niet tevens plan-MERplichtig is en (2) de windvergunning niet project-MERplichtig.

Ten derde vragen wij ons af in hoeverre de subsidieprocedure zal afwijken van de vergunningverleningsprocedure zonder subsidie. Het lijkt ons onwenselijk dat voor de subsidieverlening andere rangschikkingscriteria gelden dan voor de rangschikking van de vergunning zonder subsidie. In ieder geval zien wij geen ratio voor een verschil in criteria aan de windvergunningverlening met of zonder subsidie. Meer principieel is de vraag of de subsidie de windvergunningverlening zou moeten volgen in plaats van het huidige voorgestane omgekeerde systeem. De voorwaarden waaronder de activiteit (het realiseren van een windpark) mag worden verricht, zouden dan centraal staan in plaats van de financiële aspecten van die activiteit.

Ten vierde is een interessante vraag of de windvergunning niet alleen een 'vergunning' is, maar ook een 'concessie'. Nu net als bij een concessie sprake is van de verlening van een alleenrecht, zouden wij verwachten dat de wetgever hier in de wetsgeschiedenis aandacht aan besteedt. De kwalificatie als concessie is van belang, omdat onder omstandigheden een concessie aanbestedingsplichtig kan zijn.

Ten slotte achten wij de versnippering van de rechtsbescherming tussen de Afdeling en het $\mathrm{CBb}$ onwenselijk. De Afdeling wordt bevoegd te oordelen in geschillen over het kavelbesluit en het $\mathrm{CBb}$ over de windvergunning en subsidie. Volgens ons is er dusdanig veel samen- hang tussen het kavelbesluit, de vergunning en de subsidie dat geschillen hierover bij één rechter zouden moeten liggen. Onze voorkeur ligt bij de Afdeling, omdat het realiseren van een windpark grote gevolgen heeft voor de ruimtelijke ordening van de Nederlandse kust en op de langere termijn subsidieverlening niet meer nodig is.

De wetgever heeft zich veel inspanning getroost om met 'tailormade' regelgeving tegemoet te komen aan de gesignaleerde problemen bij de realisatie van de windparken op zee. Er is zelfs een nieuwe rechtsfiguur voorzien, bestaande toetsingskaders worden gecoördineerd en initiatiefnemers worden ontzien door het verleggen van de onderzoekslasten. Als de wetgever nu nog enkele onduidelijkheden wegneemt, dan biedt het wetsvoorstel een mooie basis voor de realisatie van de offshorewindsector. 